\title{
Students applying their knowledge of material science in problem-solving: implications for competence based-learning at the University of Zimbabwe
}

\author{
Peter Kwaira*
}

doi: http://dx.doi.org/10.18543/tjhe-4(2)-2017pp353-387

\begin{abstract}
This study involved a class of serving teachers in their second year of a Bachelor of Education degree programme, in which one of the pre-requisite courses covered during first year was 'Principles of Material Science (PMS). At the time of study, they were studying 'Machine-shop Practice' (MsP); a course based on the Design and Technology (D\&T) approach, in terms of teaching and learning. They were required to solve practical-technical problems through hands-on practical activities, supported by relevant ancillary theory. In practice, during such activities, students are expected to demonstrate the ability to apply their knowledge of Material Science (MS) in various ways; for example, in the choice of materials for given projects aimed at solving specific problems and in the methods of working such materials. Now given this background, the problem was therefore to determine the extent to which students applied their knowledge of MS in solving selected problems under MsP. Data were gathered through interviews, discussions, observations and document analysis. Findings showed students being able to apply their knowledge of MS effectively during problem-solving under MsP; thereby, qualifying their learning as having been outcome-based in nature.
\end{abstract}

Keywords: Curriculum change and innovation; design and technology; outcomebased learning; problem-solving; teaching; learning; Technical Education.

\section{Introduction and background to the problem}

The Department of Technical Education (DoTE) at the University of Zimbabwe (UZ) has been involved in the education, training and professional development of technical subject teachers since 1987. Teachers come to the Department for a Bachelor of Education (B.Ed.) degree after qualifying to

* Peter Antonio Kwaira (Petkwaira@gmail.com), PhD in Science and Technology Education, is Senior Lecturer at the Department of Technical Education, University of Zimbabwe (Zimbabwe). More details are available at the end of this article. 
teach specific technical subjects from various technical teachers' colleges around the country. Such subjects include; Wood Technology, Metal Technology, Building Technology, Technical Graphics, Agriculture and Home Economics. This study mainly focused on teachers specializing in the first two. As a requirement, teachers usually join the Department after at least two years of teaching experience in schools.

The UZ, through DoTE, introduced the said programme in 1987 at the request of the Government of Zimbabwe, through the Ministry of Education, which had just adopted a new philosophy in the teaching/learning of technical subjects; Design and Technology (D\&T). This marked the advent of D\&T as a new concept in the curriculum. Since then, D\&T has always featured both, as a subject and as an approach in the teaching/learning of technical subjects.

The move by Government to introduce D\&T was mainly motivated by the need to keep the curriculum abreast of global trends, regarding Technical Education (TE), with specific reference to curriculum change and innovation. ${ }^{1}$ Curricula the world over are changing rapidly, and in Zimbabwe as elsewhere, there has been need to relate teacher education and training to the prevailing politico-socio-economic demands of the curriculum, which now includes D\&T within the context of TE.

In recent years, TE has made spectacular advances and the societies in which we live, work, and learn have undergone some dramatic changes. ${ }^{2}$ During a national conference on the theme, 'Teacher Education for the $21 \mathrm{st}$ Century: Issues and strategies' in 2000, the then permanent secretary for the Ministry of Higher and Technology Education in Zimbabwe expressed the need for developing a teacher education system that would be responsive to the prevailing social, political and economic changes in the country. ${ }^{3}$ This reinforced the speech by the then Minister of the same ministry, when he officially opened the conference, expressing the need for continued renewal and review of teacher education and training. Delegates were challenged to address the issue of quality, particularly in teacher education and higher education in general ahead of the new socio-politico-economic era of an emerging millennium. The need for a paradigm shift was also

${ }^{1}$ National Conference on Teacher Education Report (NCTER), Teacher education for the 21st. century: Issues and strategies (Harare: Ministry of Education and Culture, Zimbabwe, 2000).

2 John P. Keeves and Glen S. Aikenhead, "Science curriculum in changing world," in Improving science education, ed. B.F. Fraser and H.J. Walberg (Chicago: The National Society for the Study of Education, 1995), 13-45.

${ }^{3}$ National Conference on Teacher Education Report (NCTER), Teacher education for the 21st. century: Issues and strategies, 1. 
emphasised, regarding focus on quality of the teaching force as opposed to mere quantity.

Historically, technical subjects in Zimbabwe (e.g., Woodwork and Metalwork), have always been taught through the traditional approach, where teachers would present pupils with problem situations and then proceed to provide solutions to those situations. A typical example could be a case where a teacher asks pupils to make a tea-pot stand for their mothers and then proceed to stipulate the material(s), measurements, and the type(s) of joint(s) required to join the various components together. ${ }^{4}$ Pupils would then be required to simply follow instructions relating to laid down procedures. The teacher would give knowledge and learners would be recipients expected to retrieve relevant bits and pieces of information as required, especially in examinations. It is such a banking concept of education that Paulo Freire has critiqued in his thesis; 'Pedagogy of the Oppressed' . In 'The Politics of Education, Culture, Power and Liberation', he (Freire) has maintained his criticism of the metaphor of education as banking, elaborately equating the business of education under this metaphor to the act of deposition in which students become the depositories while the teacher is the depositor. ${ }^{6}$ Freire describes how people of conscience can move through different stages to ultimately be able to take action and overcome oppression. ${ }^{7}$ To effect major change, at what he calls critical transformation stage, people must become active participants in changing their own status through social action, aimed at the larger social order. Here Freire's views of critical constructivism are in agreement with those of Vygotsky ${ }^{8}$ Meachum, ${ }^{9}$ Donald, Lazarus and Lolwana ${ }^{10}$ in their deliberations on social constructivism.

${ }^{4}$ Peter Kwaira, "Problems experienced by teachers in their efforts to implement the Design and Technology approach in the teaching of technical subjects," in IDATER'98, ed. Smith, J.S (Department of Design and Technology, Loughborough University, 1998), 224-229.

${ }^{5}$ Paulo Freire, Pedagogy of the oppressed (Englewood Cliffs N.J.Prentice Hall, 1972).

${ }^{6}$ Paulo Freire, The politics of education, culture, Power and liberation (South Hadley, Mass.: Bergin\&Garvey, 1985).

7 Allan C.Ornstein and Francis P. Hunkins, Curriculum foundations, principles, and issues (London: Allyn and Bacon, 2004).

${ }^{8}$ Lev S.Vygotsky, Thought and language, ed. Alex Kozulin (Cambridge: The MIT Press, 1986).

${ }^{9}$ Meachum J. Shuaib, "Vygotsky and the blues: Re-reading cultural connections and conceptual development," Theory into Practice 40 (2001): 190-197.

${ }^{10}$ Reuven Lazarowtz and Pinchas Tamir, "Research on using laboratory in science instruction," in A handbook of research in science teaching and learning, ed. D. Gabel (New York: Macmillan), 94-128. 
Freire also advocates for dialogue or match between students and teachers, and for sensitivity to change ${ }^{11}$ From a much earlier debate, Freire refers to what he terms; a curriculum of 'Human phenomenon - Problematic situations - and Background awareness', which he claims has the potential to transform the world..$^{12}$ Accordingly, the curriculum focuses on community, national and world problems; and has to be based on core or inter-disciplinary approaches. Seigfried; ${ }^{13}$ Pinar $^{14}$ and Marsh and Willis, ${ }^{15}$ being reconceptualists and critical theorists, see the thrust of such a curriculum being the development of individual self-actualization and freedom through cognitive and intellectual activities, which would in turn liberate people from the restrictions, limitations and negative controls of society. These theorists are primarily concerned about people and curriculum experience rather than the curriculum planned. They suggest educators shift their attention from curriculum development to curriculum understanding. This indicates a progressive shift from knowledge to activity, theory to practice and reflections to actions in a situation, where the curriculum attempts to create new conditions and environments for the benefit of humanity. ${ }^{16}$ This implies practice and activity becoming more meaningful when guided/informed by knowledge and theory, thereby suggesting a close relationship between these factors. One can draw parallels between Paulo Freire's ideas and the main ideals founded in D\&T, especially on the issue of translating theory into practice. 'Parallels and relationships' in this case do not imply Freire's ideas and the ideals of D\&T being exactly the same! The key word is 'similarity', where if one was to argue for, and agree with the fact that Paulo Freire, in his thesis 'Pedagogy of the Oppressed' puts forward a proposition to promote 'Education for Liberation' (liberation of the mind regarding independent thinking and decision making), s/he would find traits of such education in D\&T. In this regard, Freire's ideas closely relate to the ideals of D\&T when the problem-solver is expected to make independent decisions during problem-solving. Therefore, going by Freire's contention relating to the essence of $\mathrm{D} \& \mathrm{~T}$, such a person would be regarded

${ }^{11}$ Paulo Freire, Pedagogy of the oppressed (New York: Continuum, 1990).

12 Paulo Freire, Pedagogy of the oppressed (New York: Herder \& Herder, 1970), 75-108.

${ }^{13}$ Haddock C.Seigfried, Pragmatism and Feminism (Chicago: University of Chicago Press, 1996).

${ }^{14}$ William F. Pinar, "Farewell and celebrate," in Contemporary curriculum discourses, ed. William F. Pinar (New York: Peter Lang, 1999), 489.

${ }^{15}$ Colin J. Marsh and George Willis, Curriculum: Alternative approaches, ongoing issues (Columbus, Ohio: Merrill, 2003).

${ }^{16}$ Allan C. Ornstein and Francis P. Hunkins, Curriculum foundations, principles, and issues (London: Allyn and Bacon, 2004). 
as being free/liberated in terms of thinking and decision-making. Problemsolving involves one being creative in combining established and known rules/principles into new elements to solve a given problem. ${ }^{17}$ The main argument appears to be a call for education that empowers learners to play an active role on matters to do with their lives/welfare. Melnick advances similar thoughts in relation to the role of virtual schools, given the changing face of education with the advent of the $21^{\text {st }}$ century:

Virtual schools should hold out the possibility of the global classroom, democratization of knowledge, student-driven learning, and robust, authentic curriculum that is constantly being improved upon by each successive group of learners. ${ }^{18}$

In agreement with critical theorists like Freire and Melnick, are postmodernists like: Slattery $;{ }^{19}$ Peters,${ }^{20}$ and Neville ${ }^{21}$ holding the view that there is not one way to interpret the curriculum. Post-modernists are constructivistic in viewing the world as emergent, fluid, chaotic, open, interactive and ongoing. ${ }^{22}$ This is contrary to the modernist view of a grand narrative for phenomena. According to Gagnier ${ }^{23}$ post-modernists challenge and question the grand claims proclaimed by modernists about key concepts such as justice, validity, reliability and truth. Likewise, they query the rigidity usually suggested by concepts such as curriculum, instruction, pedagogy, education, schooling, student and teacher.

A common criticism of D\&T in Zimbabwean today has been the fact that it does not play an integral role in the instructional process. ${ }^{24}$ Apart from failing to teach the subject effectively, most teachers appear to use D\&T as an approach on an extremely limited scale. While several factors seem to contribute to this problem, teacher education apparently appears to be at the

17 Mills R. Gagne, The condition of learning (New York: Holt, Rinehart and Winston, 1987).

${ }_{18}$ Blake Melnick, "Virtual Schools: The changing face of education - Learning with technology," The English Journal: The world of literature 91, no. 5 (2002): 85-88.

${ }_{19}$ Patrick Slattery, Curriculum development in the postmodern era (New York: Garland Publishing, Inc., 1995), 118.

${ }^{20}$ Michael Peters, Education and the postmodern condition (Westport, Conn.: Bergin and Garvey, 1995).

${ }_{21}$ Robert C. Neville, The high road around modernism (Albany: State University of New York Press, 1992).

22 David Harvey, The Condition of Post-Modernity (Oxford: Basil Blackwell, 1992).

${ }^{23}$ Regenia Gagnier, "Feminist postmodernism: The end of theory?," in Theoretical perspectives on sexual differences, ed. Deborar L. Rhode (New Haven, Conn.: Yale University Press, 1990).

${ }^{24}$ National Conference on Teacher Education Report (NCTER), Teacher education for the 21st. century: Issues and strategies, 2. 
core; mainly because teachers have the crucial responsibility for developing or preparing the learning environment, choosing or designing instructional strategies and deciding what instructional materials or teaching aids to use. ${ }^{25}$ If teachers do not have the necessary knowledge and skills to integrate D\&T into the curriculum as part of the instructional process, they cannot be expected to do so. Glenn and Carrier ${ }^{26}$ came to this conclusion on teachers who were expected to integrate computer technology into their teaching, but were experiencing difficulties. It was only after they had gone through an inservice programme designed to give them the necessary orientation that there were signs of progress.

At the above mentioned conference on teacher education, several resolutions and suggestions were made in view of a three-fold challenge in the professional development of technical subject teachers, where there was a critical need to;

- increase scientific knowledge in order to approach/teach technical subjects from a scientific perspective.

- enhance the competence of teachers in solving practical D\&T problems where practical skills are guided by scientific knowledge and/or principles.

- increase understanding of how to teach pupils to solve technical problems in D\&T by putting theoretical knowledge into practical application.

Such a paradigm shift called for life-long professional development, opposed to the 'one-off' programmes in most conventional colleges today.

For the purpose of this study, the following pedagogical ideas were drawn from the aims and objectives of the 2002 version of the 'A' Level D\&T syllabus developed by the Zimbabwe Schools Examination Council (ZIMSEC) in collaboration with the Cambridge International Examinations (CIE):

- Problem posing, as opposed to the traditional approach where learners were presented with solutions to problems.

- Learners and teachers brain storming over possible solutions to practical problems.

${ }^{25}$ Terry W. Moore, Philosophy of education - An introduction (London: Routledge and Kegan Paul, 1982).

${ }^{26}$ Allen D. Glenn and Carol A. Carrier, "Teacher education and computer training: An assessment (Beyond the computer revolution)," Peabody Journal of Education 64, no. 1 (1986): 67-80. 
- Learners working in groups and collaborating in the business of learning.

- Teaching and learning being learner-centred.

- Learners contributing towards assessment of their work through selfassessment.

- Learners being able to record their ideas in design folios during problem-solving.

- Learners experimenting with various materials.

- Promotion of subject integration between MS and other subjects in the curriculum.

- Technical subjects becoming more and more scientific in orientation within the context of D\&T.

It is indeed some of these ideas that guided this study. After their 2-year B.Ed. degree programme, the teachers involved were expected to go back to their schools around the country and implement what they would have learnt. This implied several connotations in relation to the issue of outcome and/or competence-based learning. Teachers being able to apply their newly acquired knowledge and skills in their teaching practice meant a lot, in terms achievement for the whole education system! Out of several possibilities, the main focus of study was on the need to have students (serving teachers) actively demonstrating and reflecting on their understanding of specific concepts within particular subject areas. In this case, one of the pre-requisite courses they had done in their first year was 'Principles of Material Science (PMS). At the time of study, the teachers were in their second year studying Machine-shop Practice (MsP), where they were expected to solve practical problems through hands-on activities. They were also expected to demonstrate the ability to apply their knowledge of Material Science (MS) in such activities. Now given this background, the problem was therefore to determine the extent to which they actually applied their knowledge of MS in solving selected problems under MsP.

\section{The theoretical framework and related perspectives}

From a theoretical perspective, the following issues were pertinent: The essence of curriculum change and innovation; Linking theory and practice in problem-solving within the context of D\&T, and Current debate on issues relating to outcome-based learning. 


\section{II.1. The essence of curriculum change and innovation}

Curriculum change and innovation has to do with the question of 'relevance'. ${ }^{27}$ It is usually necessitated by the need to make the curriculum relevant to a particular context. According to Cornbleth, ${ }^{28}$ calls for reform signify dissatisfaction, impatience and optimism; thereby, confirming the belief that people are rarely content with things as they are. Naturally people always expect greater quantity and quality than whatever presently exists. ${ }^{29}$ On education and schooling, this explains the relentless search for excellence, where the curriculum has remained under the spot-light, challenged to keep abreast of unpredictable events in society. ${ }^{30}$

Since different politico-socio-economic situations exist in different countries, educational problems tend to be relative, depending on the particular needs of individual societies. ${ }^{31}$ This brings in the issue of 'curriculum relevance', where English ${ }^{32}$ views the curriculum in terms of ideological (or philosophical-scientific), technical (or design), and operational (or managerial) issues.

To argue that curriculum should be relevant or useful does not mean much unless we know whom it should be useful to, what purpose it should be useful for, and in whose judgement it should be useful..$^{33}$ Accordingly, activities do not possess or lack relevance in the abstract. They possess or lack relevance to particular people, for particular purposes, and in particular circumstances. In this case, society and the individual are of particular interest.

Curriculum content largely depends on the nature of society. ${ }^{34}$ Hence, any society sophisticated enough to have an idea of education is most likely

${ }^{27}$ Alex C. Bowers and David J. Flinders, Responsive teaching (New York: Teachers' College Press Columbia University, 1990).

${ }^{28}$ Catherine Cornbleth, "Ritual and rationality in teacher education reform," Educational Researcher 15, no. 4 (1986): 5.

${ }^{29}$ Cornbleth, "Ritual and rationality," 5-14.

${ }^{30}$ Michael W. Apple, "The politics of official knowledge in the United States," Journal of Curriculum Studies 22, no. 4 (1990): 377-383.

${ }^{31}$ Herbert Kohl, Towards educational change and economic justice (Phi Delta: Kappan, 1991), 678-681.

${ }^{32}$ Fenwick W. English, "Contemporary curriculum circumstances," in Fundamental curriculum designs, ed. FenwickW. English (Michigan: University of Michigan, 1983), 1-17.

${ }^{33}$ Robin Barrow, Giving teaching back to teachers: A critical introduction to curriculum theory (Sussex: Wheatheaf Books, 1984).

${ }_{34}$ Jon Wiles, Curriculum essentials: A resource for educators (New York: Pearson Education, Inc., 2005). 
to regard some knowledge and skills as worthy of passing on to the next generation. What is judged as valuable depends on several factors where, among many, Kelly ${ }^{35}$ gives; different epistemological styles, different cultures, and different stages of development. Moore ${ }^{36}$ also refers to a position held by some sociologists of education who, following a Marxist persuasion, maintain that any educational curriculum reflects an interest.

Apart from society, the 'individual learner' is also considered under the issue of 'curriculum relevance'. Whatever context, the learner is key to the success of any curriculum. ${ }^{37}$ Society might endeavour to achieve certain ideals but, if the learner's interests are not accommodated, not much might be achieved! Garforth ${ }^{38}$ goes further to point out that, politicians, policy makers, school administrators and teachers might agree on what they might consider to be a wonderful curriculum, only to find the wrong students showing up! Garforth appears to agree with Kilpatrick's ${ }^{39}$ work, focusing on the 'childcentred curriculum', which according to Ginsburg, belongs to the doctrine of 'child-social-purpose', based on the 'activity-centred curriculum'.

Perhaps, Kilpatrick's work could best be explained by the more recent debate raised by Berlak and Berlak,$^{40}$ focusing on three main dilemmas from among several, regarding the choice of knowledge patterns in a curriculum: (a) knowledge as given versus knowledge as problematic, (b) public knowledge versus personal knowledge, and (c) knowledge as molecular versus knowledge as holistic. Given the profile of controversies and contradictions implied in these areas, the direction one takes depends on one's line of thinking, resulting in a particular outlook of the curriculum in a particular context. McNeil ${ }^{41}$ draws similarities between Kilpatrick's work

${ }^{35}$ Victor A.Kelly, Curriculum context: A comparative approach (London: Happer and Row Publishers, 1980).

${ }^{36}$ Moore, Philosophy of education.

${ }^{37}$ Peter Kwaira, "A study to determine the extent to which the Design and Technology approach is being relevant to the teaching of technical subjects in Zimbabwe," in Proceedings of the eighth annual meeting of the Southern African Association for Research in Mathematics and Science Education, ed. Sechaba Mahlomaholo (Port Elizabeth: University of Port Elizabeth, 2000), 239.

${ }^{38}$ Kwaira, "A study to determine the extent to which the Design and Technology approach is being relevant to the teaching of technical subjects in Zimbabwe," 239-246.

${ }^{39}$ Heard W. Kilpatrick, Foundation of education (New York: Macmillan, 1926), 212.

${ }^{40}$ Ann Berlak and Harold Berlak, "Towards a non-hierarchical approach to inquiry and leadership," Curriculum Inquiry 13, no. 3 (1983): 267-294.

${ }^{41}$ John McNeil, Curriculum: A comprehensive introduction (Glenview III: Scott Foreman, 1990). 
and that of Dewey. ${ }^{42}$ However, the main difference between these two architects/philosophers of education is that while Kilpatrick focuses on the role of the child in an educational enterprise, Dewey focuses more on the teacher's role. For Kilpatrick, the child has to learn to search; investigate, compare, think why and in the end, make his/her own decision as required in a given situation. According to the thinking in this study, this is exactly what $\mathrm{D} \& \mathrm{~T}$ is all about!

Barrow $^{43}$ identifies four causes of irrelevance in education and consequently, four levels on which relevance may be achieved: what is taught, how it is taught, learners' feelings and the learners' concerns. In practically all societies, rapid change is occurring in roles and relationships, economic conditions, mores and values, religious and political beliefs, relations between nations, and ways of everyday life. ${ }^{44}$ These and other changes implicitly and explicitly challenge us to re-think the curriculum. ${ }^{45} \mathrm{In}$ most cases profound changes are needed in school curricula and in government policies to meet the challenge, hence the need for reform(s) in education, both 'radical' and 'gradual' ${ }^{46}$ In Zimbabwe, the latter, also known as 'continuous/rolling' reforms are currently the main focus in view of the need to have the education system in line with the prevailing politico-socioeconomic conditions.

The need for such continuous revision of the curriculum is actually related to the rapid and erratic shifts, qualitatively and quantitatively, in the 'social demand' for education as well as in the 'economic demand' for educated people. ${ }^{47}$ Hence, it is affirmed, if 'rolling reform' is to have any meaning or impact, it must be possible to identify, and to some extent predict, such shifts. ${ }^{48}$ In most countries today, the majority of citizens must be prepared to change occupations once or twice during their working lives, or to undergo a so thorough re-training that it becomes equivalent to a complete

${ }^{42}$ John Dewey, "Individuality and experience," in Art and Education, ed. John Dewey (Marion, Pa.: Barnes Foundation, 1929), 180.

${ }^{43}$ Barrow, Giving teaching back to teachers, 2.

${ }^{44}$ Moore, Philosophy of education, 2.

45 Wayland Bowser, "Reforming design education," Journal of Architectural Education 37, no. 2 (1983): 12-14.

${ }^{46}$ Jonas R. Zvobgo, Transforming education: The Zimbabwean experience (Harare: The College Press, 1986).

${ }_{47}$ National Conference on Teacher Education Report (NCTER), Teacher education for the 21st. century: Issues and strategies, 3.

${ }^{48}$ National Commission for Excellence in Teacher Education (NCETE), A call for change in teachers education (Washington, DC: American Association of Colleges in Teacher Education, 1985). 
change of occupation. There is also constant development and change in subjects and materials used in education. All these developments affect the context in which the work of the school is performed.$^{49}$ It is becoming less important for schools to spend time teaching about facts that probably will soon become obsolete. By implication, in D\&T, the practical skills we teach have to be relevant; otherwise they would not be applicable in problemsolving. Where technological advances occur, for example in industry, what we teach in schools particularly practical skills would accordingly need to keep abreast of events in the world of work. Barrow ${ }^{50}$ warns of the danger of 'inert ideas', and argues that education founded upon such ideas is not only useless; it is harmful.

\section{II.2. Linking theory and practice in problem-solving within the context of $D \& T$}

Important lessons were in this case drawn from Science and Technology (S\&T), regarding current practices and issues in practical work. According to Mafumiko and Ottevanger ${ }^{51}$ there is a strong conviction among teachers and researchers that hands-on activities have the potential to develop various student abilities in Science and related subjects like D\&T. However, several investigations have recently proved that in many classrooms and laboratories there are serious discrepancies between the lofty goals expressed in the rhetoric of S\&T education and the kinds of activities in which students engage. ${ }^{52}$ Mafumiko and Ottevanger ${ }^{53}$ agree with Ware ${ }^{54}$ when they argue that in some schools, especially in developing countries, there is no laboratory work at all. In others, there is hands-on practical work, but students follow a list of step-by-step instructions like technicians trying to reproduce expected results and struggling to get the right answers without question. This also

${ }^{49}$ Carlson J. Powell and Ronald D. Anderson, "Changing teachers' practice: Curriculum materials and science education reform in the USA," Studies in science education 37 (2002): 107-136.

${ }^{50}$ Barrow, Giving teaching back to teachers, 2.

${ }^{51}$ Fidelis Mafumiko and Wout Ottevanger, "Micro-scale experiments in improving practical chemistry in Tanzania secondary science education," in Science education research and teacher development in Tanzania, ed. Osaki K et al. (Amsterdam: VrijeUniversiteit Amsterdam - International Cooperation Centre, 2002), 121-134.

${ }^{52}$ Sylvia Ware, Secondary school science in developing countries (Washington, DC: The World Bank, 1992).

${ }_{53}$ Mafumiko and Ottevanger, Science education research, 121-134.

${ }^{54}$ Sylvia Ware, Secondary school science, 1. 
explains the criticisms levelled against the traditional approach to the teaching/learning of technical subjects, where a lot of practical work goes on with pupils/students following laid down procedures, using recommended materials and tools, for example. Unfortunately, this is a negation of creativity and emancipatory principles, where learners are expected to make independent decisions in problem-solving as propounded by Paulo Freire in his 'Pedagogy of the Oppressed'. ${ }^{5}$

The issue is not simply the teaching/learning of skills, but rather about the nature of skills one would be aiming at promoting. If our aim is to promote the ideals of D\&T, then we would worry about rationality, where one engages in informed decision making. This is what differentiates human beings from animals.$^{56}$ While there have been cases of some animals performing certain tasks better than human beings, one would still not declare them rational, from a philosophical perspective; thereby suggesting a distinction between instinct and rationality. ${ }^{57}$ On teaching/learning, what we would like to see is not just the mere promotion of practical skills, but the development of skills being accompanied by critical thinking and informed/rational decision making.

However, Bradley ${ }^{58}$ presents evidence on cases where teachers do not attempt to do practical work with pupils even when there are adequate facilities and resources. In such cases, the blame is levelled on lack of proper teacher preparation and professional development programmes with regard to practical work at both, pre-service and in-service levels. Having learnt this much from S\&T, one could then see why in this study the intention was to link the two courses; MS and MsP. Such a relationship was necessitated by the need to put theoretical knowledge (MS) into practical application under MsP while at the same time being aware of one of the main areas of foci spelt out earlier in this study; 'enhance the competence of teachers in solving practical D\&T problems where practical skills are guided by scientific principles' .

\section{II.3. Current debate on issues relating to outcome-based learning}

While we can debate and differ as to the specific purpose of education, not many of us will disagree that education is purposeful. We create curricula

${ }_{55}$ Ornstein and Hunkins, Curriculum foundations, principles, and issues, 2.

${ }_{56}$ Barrow, Giving teaching back to teachers, 2.

${ }^{57}$ Stanley R. Peters, The philosophy of science (London: Oxford University Press, 1973).

58 John D.Bradley, "Science education at the RADMASTE Centre: The role of the university in development," in Science and environment education: Views from developing countries, ed. S. Ware (Washington: The World Bank,1999), 41-150. 
of various designs for both general and specific intentions. Indeed, those who develop curricula and teach it have some intent in mind. Discussing the aims and goals of education, Ornstein and Hunkins ${ }^{59}$ also maintain that education is enacted for a reason; emergent and random. It is an intentional activity created to allow students to attain specific understandings, skills and attitudes that would enable them to participate meaningfully in their world; current and future. ${ }^{60}$

The fact that some intents in education are geared towards the immediate while others are geared towards the long term justifies and explains the place for objectives and aims in education. Respectively, objectives are for the immediate and aims are for the long term. ${ }^{61}$ For example, while we may precisely indicate that after studying a unit covering a particular technical skill, a student would produce an artefact demonstrating an understanding of the behaviour of materials under specific conditions, the implication is that in future, the individual would apply such a skill in ways as yet unknown/ unspecified. Moreover, as educationists we hope/assume, what the student does with this skill will demonstrate wise application of knowledge for personal and social benefit. ${ }^{62}$

In times of rapid change such as we have today, in practically every country, society expects schools to help citizens adjust and this has implications for curriculum development as observed by Cornbleth ${ }^{63}$ in her discussion of 'Curriculum in Context'. She argues that curriculum construction is an on-going social activity, shaped by various factors within and beyond the classroom, accomplished interactively and primarily by teachers and students. The curriculum becomes highly constructivistic in nature as explained by Oxford ${ }^{64}$ in a phenomenon she terms shape-shifting; implying the quick adjustment of functions in situations of rapid change. In a related discussion, Oxford ${ }^{65}$ refers to the concept of social constructivism, where development is guided by social events/trends. Perhaps, this is why in most cases society has often compelled schools to modify their programmes in order for learners to function more effectively. Usually, this has called for a revisit of the aims of education in order for those aims and their objectives

${ }^{59}$ Ornstein and Hunkins, Curriculum foundations, principles, and issues, 3.

${ }^{60}$ Catherine Cornbleth, Curriculum in context (New York: The Falmer Press, 1990).

${ }^{61}$ David Pratt, Curriculum planning (New York: Harcourt Brace College Publishers, 1994).

62 Pratt, Curriculum planning.

${ }^{63}$ Cornbleth, Curriculum in context.

${ }^{64}$ Richardson L. Oxford, "Constructivism: Shape-shifting, substance, and teacher education applications," Peabody Journal of Education, 72, no. 1 (1997): 35.

${ }^{65}$ Oxford, "Constructivism," 35-66. 
to remain relevant and appropriate in given contexts. ${ }^{66}$ For example, in a problem-solving situation, aims are the starting point for an ideal or inspirational vision of the good. In this respect, aims reflect value-laden judgements that help to guide the educational process. This is why the intention in this study was to determine the extent to which teachers were actually applying their knowledge of MS in problem-solving under MsP. As educators, we are challenged to interpret the aims of education in relation to those of society. For this study, the general aims of teacher education in Zimbabwe were the main focus. Several lessons were drawn from Doll ${ }^{67}$ who summarizes and interprets the following dimensions of what American aims of education should address:

(a) The intellectual/cognitive - Aims focusing on acquisition/ comprehension of knowledge, problem-solving skills, and various levels of thinking

(b) The social-personal or affective - Involving person-to-society, person-to-person, and person-to-self interactions

(c) The productive - Aiming at allowing/enabling the individual to function in the home, on the job, and in society

According to Sowell ${ }^{68}$ these goals furnish answers to the following question: "What destination do you have in mind for learners as far as a particular curriculum or subject is concerned?" In this case, the destination intended for the concerned teachers was for them to end up being able to teach MS effectively in schools through the D\&T approach.

However, while goals suggest intended destinations, they do not specifically denote particular learning. Rather, goals address certain characteristics of the learner on attainment of the stated goals ${ }^{69}$ For example, a curriculum that aims at developing learners into resourceful citizens, would most likely try to ensure that learners are skilled in the art of critical thinking, are responsible and have the capacity to work with people from all walks of life. Effectively the point is, when discussing or recommending goals in their generality, we do not pick on specific items for learning, but we highlight the 1994).

${ }^{66}$ Chris Kyriacou, Effective teaching in schools (New York: Simon\&Schuster Education,

${ }^{67}$ Ronald C. Doll, Curriculum improvement: Decision making and process (Boston: Allyn and Bacon, 1996).

${ }^{68}$ Evelyn J. Sowell, Curriculum: An integrative introduction (Upper Saddle River, NJ: Merrill-Prentice Hall, 1996).

${ }^{69}$ George J. Posner, Analysing the curriculum (New York: McGraw-Hill, 1992). 
qualities or characteristics that we expect in someone after learning several relative items, depending on the demands of a given context. ${ }^{70}$

Having dealt with the issue of educational goals from a general perspective, it is now perhaps appropriate to relate the issue more closely to the purpose of this study. Ornstein and Hunkins ${ }^{71}$ maintain:

When speaking of goals, we are addressing curriculum goals or desired outcomes for students as a result of experiencing the curriculum. We are not addressing how teachers would instruct students to achieve these goals, although it is realized that instruction is related to the curriculum and that particular methods of instruction are selected mindful of the demands of certain contents and also the demands of students and their ability and interests.

A close study of this argument shows several threads in common with the principles and ideas assumed to have been employed in the design, development, implementation and evaluation of the two course outlines at the core of this study. Most of these are clearly located within the aims and objectives. What seems to be coming out clearly here is that the distinction between aims and goals of education is one of generality, where aims deal with the general process of education, such as 'developing problem-solving abilities' or 'creating technological literacy.' According to Harris et.al., ${ }^{72}$ no specific program or course in a particular school will attain all the aims that there might be. Several aspects of curriculum are likely to address them; thereby suggesting aims only becoming goals when they become more specific in relation to a particular school system and to a specific subject area. For example, in relation to this study, the broad aims from the said B.Ed. degree programme could only become manageable when they led to goals; in turn reduced to objectives within the limits of the course-outlines.

In Zimbabwe, we are currently going through a period that is characterized by rapid and continuous change. Most of these events and changes have been closely related to the serious political and economic challenges currently prevailing. Therefore, one sees the relevance and validity of Dewey's ${ }^{73}$ argument, maintaining that the ends to which we strive are not really ends,

${ }^{70}$ Posner, Analysing the curriculum, 1.

${ }^{71}$ Ornstein and Hunkins, Curriculum foundations, principles, and issues, 4.

${ }^{72}$ Peter Harris et al., "Competency-based medical education: Implication for undergraduate programmes: For the International CBME Collaborators," in School of Public Health and Community medicine, ed. Medicine Faculty (Sydney: University of New South Wales, 2010).

${ }^{73}$ Reginald D. Archambault, John Dewey on education: Selected writings, ed. Reginald D. Archambault (New York: Random House, 1964) 74. 
but way-points on a continuous journey. According to this observation, education is a journey where our intentions, however phrased, must inform the learner that the attainment of a way-point enables him/her to proceed or advance to the next. Taking from this assertion, this is why, even after MS, teachers were still expected to reflect upon it during MsP.

\section{Research questions}

The main research question addressed in this study went as follows: 'To what extent are students (serving teachers) able to apply their knowledge of Material Science when solving practical problems under Machine-shop Practice?'

This question was then unpacked through the following sub-questions:

- To what extent are the two courses, MS and MsP reflective of each other?

- What aspects of MS do students find being applicable to their activities in MsP?

- To what extent are students able to reflect on their knowledge of specific concepts in MS when solving practical problems? AND,

- In what activities is one able to identify specific cases of students applying their knowledge of MS in solving given practical problems?

\section{Methodology}

This study involved 23 serving teachers (16 males and 7 females), enrolled in a B.Ed. degree program with the Department of Technical Education at the University of Zimbabwe. These were qualified teachers drawn from schools all over the country.

Data gathered through interviews, observations and document analysis of course outlines and design folios were mainly analysed qualitatively, with the aid of specially designed schedules and checklists. In addition, observations of workshop activities were also supported by photographs and video filming. Most observations were made during both, class and workshop activities.

On the other hand, the document analysis of design folios was done specifically focusing on one particular project, involving the design and 
development of a toy encompassing variously mechanisms. From a common design brief (Going as follows: Using various materials, design and make a toy that you could use to teach about the application of at least three mechanisms), students were expected to come up with a variety of designs. Completion of project was then followed by the document analysis folios, with the aid of a specially crafted schedule based on a skeleton of the following key items:

STAGE 1: Problem situation for design

STAGE 2: Design brief and specifications

STAGE 3: Investigation and market research

STAGE 4: Possible solutions

STAGE 5: Chosen solution

STAGE 6: Realization (Path analysis and routing)

STAGE 7: Evaluation

These stages were vivid sections in folios, thereby resulting in the analysis being a straight-forward exercise. The idea of treating every folio as an individual case was adapted from the usual applications in areas as disparate as those outlined by Robson $;{ }^{74}$ psychiatry, administration, anatomy, anthropology, clinical medicine, counselling, criminology, military studies and social work. In case studies, a case/site refers to the specific/particular situation, individual, group, organization or whatever it is that we might be interested in. ${ }^{75}$

In this study, strategies for dealing with cases in other disciplines provided useful lessons, suggesting solutions to problems with case study methodologies, including the thorny issue of generalizing from individual cases. During the design of this study, such lessons proved useful in planning for what Robson ${ }^{76}$ has refers to as 'rigorous case studies' like those conducted here, given the need to evaluate the work in the 23 design folios.

According to the 'Zimbabwe Education Blueprint 2015-2022: Curriculum Framework for Primary and Secondary Education', a 'design folio' is a document comprising the above outlined stages, arranged into 7 sections in a collection of A3 or A2 sheets of cartridge paper written/drawn on one side and bound together into a folder. It is actually a diary of what students record during their design and problem-solving activities. This definition of design

${ }^{74}$ Colin Robson, Real world research: A resource for social scientists and practitionerresearchers (Oxford, UK: Blackwell Publishers, 1993).

${ }^{75}$ Quinn M. Patton, Qualitative research and evaluation methods (London: Sage Publications - International and Professional Publisher, 2002).

${ }^{76}$ Robson, Real world research, 1. 
folio appears very much in line with Garratt's ${ }^{77}$ description of the same, referring to a collect of sheets of cartridge paper in form of a journal/logbook. In this study, this was then the document that students were expected to compile for their design projects, thereby allowing them to keep track of their thoughts, ideas and activities. Such a record allowed them the flexibility to revisit their ideas whenever necessary; typical of the design process.

Given the quantity of materials in the 23 design folios that were to be evaluated and analyzed, there was need to device a tool that would enable one to capture all relevant/appropriate data for analysis. This is where the instrument in Figure 4.1 was used. The idea was to focus on the notes, sketches and records in every section of a given folio and identify any aspects in form of ideas, arguments and decision making processes influenced by perceptions, understanding and knowledge of MS. A typical example could be a case where one would be trying to choose a particular material from among many, for a specific application in problem-solving. Figure 5.4 shows details on how this instrument was then used.

\begin{tabular}{|c|c|c|c|c|c|c|c|c|}
\hline $\begin{array}{c}\text { Folios } \\
\downarrow\end{array}$ & $\begin{array}{c}\text { Stage 1 } \\
\text { (Section } \\
\text { 1) }\end{array}$ & $\begin{array}{c}\text { Stage 2 } \\
\text { (Section } \\
\text { 2) }\end{array}$ & $\begin{array}{c}\text { Stage 3 } \\
\text { (Section } \\
\text { 3) }\end{array}$ & $\begin{array}{c}\text { Stage 4 } \\
\text { (Section } \\
\text { 4) }\end{array}$ & $\begin{array}{c}\text { Stage 5 } \\
\text { (Section } \\
\text { 5) }\end{array}$ & $\begin{array}{c}\text { Stage 6 } \\
\text { (Section } \\
\text { 6) }\end{array}$ & $\begin{array}{c}\text { Stage 7 } \\
\text { (Section } \\
7)\end{array}$ & $\begin{array}{c}\text { Total } \\
\text { Scores }\end{array}$ \\
\hline 1 & & & & & & & & \\
\hline 2 & & & & & & & & \\
\hline$\downarrow$ & & & & & & & & \\
\hline 23 & & & & & & & & \\
\hline
\end{tabular}

Figure 4.1

Skeleton of the tool used to evaluate and analyse data from the 23 folios

Stages 1-7 in Figure 4.1 are actually the 7 stages of the design process, translating into the 7 sections of the design folio, which then became the basis for scrutiny of the folios, going as follows; Problem situation for design, Design brief and specifications, Investigation and market research, Possible solutions, the Chosen solution, Realization (Path analysis and routing) and Evaluation.

${ }^{77}$ Regenia Gagnier, "Feminist postmodernism: The end of theory?," in Theoretical perspectives on sexual differences, ed. Deborar L. Rhode (New Haven, Conn.: Yale University Press, 1990). 
Essentially, the flexibility suggested by the folio as already indicated implies the problem-solving activities within D\&T being an on-going process; thereby qualifying as one of the key activities in Developmental Research (DR). DR is often initiated for complex, innovative tasks where very few validated principles are available to structure and support design and development activities. ${ }^{78}$ It is about making practical and scientific contributions, involving empirical testing of prototypes in a cyclic fashion, which is a typical feature of problem-solving in D\&T. Since the seven sections of the design folio are drawn from the design process, it is important to note that the 'Evaluation' at the seventh stage does not mean end of processes, but rather the beginning of another round of investigations through further research for the sake of improvement in a given context.

\section{Results and findings}

The results and findings of this study were presented in line with the four secondary research questions, resulting in the following:

- Material Science and Machine-shop Practice being reflective of each other

- Aspects of Material Science applicable to activities in Machine-shop Practice

- Students reflecting on their knowledge of Material Science during problem solving

- Evidence of students applying their knowledge of MS in problem solving

\section{V.1. Material Science and Machine-shop Practice being reflective of each other}

Findings here were in answer to the question: 'To what extent are the two courses, MS and MsP reflective of each other?' This question was addressed in two ways; Document/Content analysis of the two course outline, and interviews/discussions with students.

78 Jan Van den Akker, "Principles and methods of development research," in Design approaches and tools in education and training, ed. Jan van den Akker et al. (Dordrecht: Springer Science+Business Media, 1999), 1-14. 
Analysis of course outlines was mainly centred on the general aims (purpose), where the former went: 'The main purpose of this course is to give you (prospective D\&T teachers) a strong theoretical background that would enable you to teach MS at 'A' Level. Although this course is mainly theoretical, an effort will be made to include simple illustrations, demonstrations and laboratory activities, wherever possible. You will be expected to apply what you learn in this course when you go for your MsP.' AND, the latter: 'This course generally aims at affording you the opportunity to apply the theoretical knowledge acquired in various pre-requisite subjects; MS being the most outstanding. Specifically, you are expected apply such knowledge in solving practical problems encountered in various workshop situations. The same knowledge is also expected to help you making decisions/ choices, regarding what materials to use in specific problem situations, depending on the nature of problem). Solutions to problems in this case would involve the design and development of gadgets to meet specific practical/technical needs.'

An examination of these two profiles (aims) shows a close relationship between the two courses. This was also confirmed by students during group/ class focused discussions/interviews involving all the 23 participants. The following questions were presented and debated openly with all participants airing their views from various angles:

1. Would you say there is any relationship between the Materials Science you did last year and the Machine-shop Practice course you are currently doing?

2. If 'yes' to ' 1 ', in what way? AND; If 'no, why do you say so?

3 . Either way in ' 2 ', may you please give examples?

4. Given your activities in Machine-shop Practice, where exactly would you say, there has been evidence of you having applied your knowledge of Material Science?

With all proceedings captured on audio tape, the following are just a sample of transcripts from some of the outstanding views shared:

- Student 1: I think MS that we did last semester is very relevant in the MsP that we are doing now, because you find--e-e--, we are now able to--we have vast knowledge of materials that are available for us as designers and we are now being able to implement them in our designs.

- Student 2: Yes, yes, yes. Even on the cutting list of materials on the--of the toy project, I actually put the materials which I learnt in my Material Science, of which, it shows that I am actually applying what I learnt from my Material Science course. 
- Student 3: In MS, we dwelt much on materials that are used in engineering, right. And, in MSP we are now using those different types of materials--materials that we learnt in Material Science to manufacture small artefacts in our practical projects. Currently, we---we are manufacturing a simple auto-mata toy, a toy that has got different mechanisms.

- Student 4: Yes, relationship is there, especially where you have to relate materials to design. When selecting materials for prototype, on basis of what we learnt in MS.

- Student 5: Ya-a,---.There is relationship. We---we learnt about characteristics of materials and, we're applying that---in our designing course.

In fact, as they expressed their views, most students actually showed illustrations in their design folios to consolidate their arguments. Since they were expected to go and teach MS and MsP back in their schools, deliberations during these discussions are most likely to have created a lot of confidence in them. Sharing ideas through brain-storming is highly regarded in D\&T, where learners learn to listen to each other and accept each other's ideas and opinions. This also helped to dispel the culture of selfishness and individualism, where people are sometimes reluctant to share ideas. It is such values that these participants were expected to cultivate in their pupils back in schools, while at the same time assisting colleagues to do the same with their classes.

\section{V.2. Aspects of Material Science applicable to activities in Machine- shop Practice}

Findings here were in answer to the question: 'What aspects of MS do students find being applicable to their activities in $M s P$ ?'

Scrutiny of the MS course outline showed the following broad families of materials being pertinent and applicable to MsP: The Metallic; Polymeric and Ceramic.

Generally, all these materials shared a common ground under the following aspects: Chemical and physical properties; General classification of materials; The crystal structure in materials; Atoms in materials; The periodic table; Crystals and grains; The unit cell; Phase transformations in materials; Effects of the addition of other elements on the structure of pure materials; Effects of stress on materials; Effects of temperature change on materials; Methods of joining materials and Processing methods in general.

In MsP, activities are guided by broad categories placing content into two divisions; 'Practical application of knowledge' and 'Ancillary theory 
guiding practice'. It was therefore during group discussions that students were able to clarify on how they viewed and related these two categories.

With the aid of a check-list, it was possible to have students participating in the development of the impressions in Table 5.2. There were aspects and areas they found strictly belonging to ancillary/allied theory and those where the two categories were combined (putting theory and practical application together). Eventually after a long discussion, where participants shared ideas, what now features in Table 5.2 was widely agreed upon. There was also a high likelihood of participants taking this as a template to guide them in their teaching back in schools.

Table 5.2

Categorizing MS content accordingly under MsP

\begin{tabular}{|l|c|c|}
\hline \multicolumn{2}{|c|}{ Content items in the 'MS' Course Outline } & \multicolumn{2}{c|}{$\begin{array}{c}\text { Category in MsP } \\
\text { Course Outline }\end{array}$} \\
\hline & $\begin{array}{c}\text { Ancillary } \\
\text { Theory }\end{array}$ & $\begin{array}{c}\text { Practical } \\
\text { Application }\end{array}$ \\
\hline 1. ENGINEERING MATERIALS IN GENERAL & $\sqrt{ }$ & \\
\hline (a) Three families of engineering materials & $\sqrt{ }$ & \\
\hline (b) Bonding forces in different materials & \multicolumn{2}{|l|}{} \\
\hline 2. METALLIC STRUCTURES & $\sqrt{ }$ & \\
\hline (a) Metal atoms & $\sqrt{ }$ & \\
\hline (b) The periodic table & $\sqrt{ }$ & \\
\hline (c) The unit cell & $\sqrt{ }$ & \\
\hline (d) Phase transformation in metals & $\sqrt{ }$ & $\sqrt{ }$ \\
\hline (e) Effects of other element on the structure of pure \\
metals
\end{tabular}

\section{EFFECTS OF STRESS AND TEMPERATURE ON METALS}

(a) Plastic strain, permanent deformation and slip

(b) Cold work or work hardening

(c) Effects of elevated temperatures on work hardened structures

(d) Selection of annealing temperatures

(e) Effects of grain size on properties 


\begin{tabular}{|c|c|}
\hline \multicolumn{2}{|c|}{$\begin{array}{c}\text { Category in MsP } \\
\text { Course Outline }\end{array}$} \\
\hline $\begin{array}{c}\text { Ancillary } \\
\text { Theory }\end{array}$ & $\begin{array}{c}\text { Practical } \\
\text { Application }\end{array}$ \\
\hline
\end{tabular}

\section{ENGINEERING ALLOYS (Non-ferrous)}

(a) Aluminum alloys

(b) Magnesium alloys

(c) Copper alloys

(d) Nickel alloys

(e) Titanium alloys

(f) Zinc alloys

\section{STEEL, CAST IRON, DUCTILE IRON and MALLEABLE}

(a) The iron-iron carbide diagram and its phases

(b) Plain carbon and low alloy steel (equilibrium structures)

(c) Hypoeutectoid and hypereutectoid steels

(d) Hardenability of steel

(e) Stainless steels

(f) White iron, gray iron, ductile iron and malleable iron

(g) Working with iron-based materials

\section{COMPOSITE MATERIALS; Including Concrete and Wood}

\begin{tabular}{|l|c|c|}
\hline (a) Synthetic composites & $\sqrt{ }$ & \\
\hline (b) Concrete and its components & $\sqrt{ }$ & \\
\hline (c) Properties of concrete & $\sqrt{ }$ & \\
\hline (d) Special concretes & $\sqrt{ }$ & \\
\hline (e) Wood as an engineering material & $\sqrt{ }$ & \\
\hline (f) Wood macrostructure & $\sqrt{ }$ & \\
\hline (g) Wood microstructure & $\sqrt{ }$ & \\
\hline (h) Properties of wood & $\sqrt{ }$ & \\
\hline (i) Asphalt as an engineering material & $\sqrt{ }$ & $\sqrt{ }$ \\
\hline (j) Processing of composite materials & & \\
\hline
\end{tabular}




\begin{tabular}{|l|l|l|}
\hline \multirow{2}{*}{ Content items in the 'MS' Course Outline } & \multicolumn{2}{|c|}{$\begin{array}{c}\text { Category in MsP } \\
\text { Course Outline }\end{array}$} \\
\cline { 2 - 3 } & $\begin{array}{c}\text { Ancillary } \\
\text { Theory }\end{array}$ & $\begin{array}{c}\text { Practical } \\
\text { Application }\end{array}$ \\
\hline
\end{tabular}

\section{PLASTICS}

(a) The concept of polymerization

(b) Polymerization types

(c) Processing of plastics

\section{V.3. Students reflecting on their knowledge of Material Science during problem solving}

Here the findings were in answer to the question: 'To what extent are students able to reflect on their knowledge of specific concepts in MS when solving practical problems?'

Students were observed working individually and in groups. Individually they would study given design briefs in order to understand given problems. Thereafter, they would consult their MS notes, as well as visiting the library to access information on designs, materials and relevant technologies for the problems at stake.

In groups, they would do more or less the same thing (consulting their notes and searching for information), except that this time the process would involve brain-storming and sharing ideas in discussions. Besides individual work and group activities, they would also consult their lecturers wherever necessary, depending on the situation. Experiments and trials with/of various materials and mechanism were a common feature in workshops/laboratories.

\section{V.4. Evidence of students applying their knowledge of MS in problem solving}

Findings here were in view of the following question: 'In what activities is one able to identify specific cases of students applying their knowledge of MS in solving given practical problems?'

Although students had convincingly claimed to be applying their knowledge of MS in problem-solving under MsP, there was still need for verification of those claims through tangible evidence. Observations during class and workshop activities had also helped to substantiate some 
of the claims. However, there was still need to go further, checking for more evidence.

Students had been seen working, sharing ideas in groups and brainstorming over the use of materials and the relevant pieces of technology in problem-solving. What was then left was to go through their folios and find out how they reported their activities and explained themselves. This justified the content analysis of these documents. The validity and reliability of the information obtained from such sources as folios; being not so salient, was based on the fact that it was likely to be reasonably original and authentic. Students had recorded issues and events as they encountered or experienced them naturally in their daily workshop activities since these folios were actually journals for such a purpose.

After compiling notes from the 23 design folios, culminating in a 39 page document, the next step was to make sense out of the notes. This involved going through all notes, issues, phenomena and specific points at which one could have evidence of students having applied their knowledge of MS in solving practical problems during MsP.

Although information from the folios was summarized to only focus on relevant details, an effort was made to try and have it as much as possible, 'word for word' in all cases.

Since data collection from folios had been guided by the seven stages of the design process as already indicated, it was found logical to follow the same stages during data analysis. It was therefore within these stages, going by the sections in the folio that one searched for evidence of statements containing reasoning, choices and decision-making implying traits of perceptions and understandings appropriately supported by knowledge of MS.

The 39-page document comprising notes from the folios was closely studied according to the criteria in Table 5.4.1, where numbers 1-7 represented the said stages of the design process, effectively translating into respective sections of the folio. Statements (i) to (vi) are not really about issues totally independent of each other. They are simply about one checking for evidence of students having applied their knowledge of MS in solving practical/ technical problems under MsP. In many ways, the application of knowledge in this case also reflected a lot on one's perceptions and understanding in relation to given phenomena. However, experience showed that although the main purpose of analysis was to locate and identify evidence of the application of MS in folios, sense of focus tended to differ across the seven sections. Therefore, statements (i) to (vi) in Table 5.4.1 helped to differentiate sense of focus across respective sections from 1-7. For example, while in sections 1 and $\mathbf{2}$, the idea was to check on the clarity of statements relating the 'Problem 
situation for design', 'Design brief and specifications', in sections 3, 4, 5, 6 and 7 students were expected to make informed decisions, explanations and arguments relating to the selection and justification of possible solutions, materials and tools/equipment in given contexts. It was within these parameters that the application of MS was to be demonstrated.

Table 5.4.1

Matrix representing criteria for identifying and locating traits of MS in the design folios

\begin{tabular}{|l|c|c|c|c|c|c|c|c|}
\hline \multicolumn{1}{|c|}{ Statements } & Code & 1 & 2 & 3 & 4 & 5 & 6 & 7 \\
\hline $\begin{array}{l}\text { i) Clarity of relevant details as informed } \\
\text { by knowledge of MS }\end{array}$ & Det-Cla & X & X & & & X & & \\
\hline $\begin{array}{l}\text { ii) Clues implying application of MS in } \\
\text { specific statements }\end{array}$ & Ap-Clu & & X & X & X & X & & \\
\hline $\begin{array}{l}\text { iii) Evidence of choices and decision } \\
\text { making being guided by knowledge of MS }\end{array}$ & Ch\&D-m & & & X & X & X & X & X \\
\hline $\begin{array}{l}\text { iv) Appropriate use of MS knowledge in } \\
\text { explanations/descriptions of processes \& } \\
\text { procedures }\end{array}$ & Pro-Exp & & X & & & X & X & \\
\hline $\begin{array}{l}\text { v) Evidence of Material Science in } \\
\text { highlighting and focusing on relevant } \\
\text { issues }\end{array}$ & MS-Iss & & & & & X & X & X \\
\hline $\begin{array}{l}\text { vi) Evidence of appropriate use or } \\
\text { application of materials in design or } \\
\text { problem solving }\end{array}$ & Mat-App & & & & & & X & X \\
\hline
\end{tabular}

Key for Codes: (i)Det-Cla=Detail Clarity (ii)Ap-Clu=Application clues (iii)Ch\&D-m=Choices\& decisions-making (iv)Pro-Exp=Process explanation (v)MS-Iss=Material Science issues (vi)MatApp=Material application.

For the sake of clarity, the codes indicated from (i) to (vi) in Table 5.4.1 were marked throughout the hard copy of the said 39-page document containing notes from the folios. In each case, there was need to identify this evidence by means of such markings, and Figure 5.4 shows a summary of how this evidence was then transformed and reduced into a tabular record where every tick means a trait of MS according to the criteria in Table 5.4.1. These patterns were an important indication of the extent to which students had applied their knowledge of MS in solving practical problems at various levels during MsP. This was also a way of corroborating what they had claimed during interviews and discussions regarding their application of MS in MsP. 
Although all the 23 folios had evidence of one form or another as outlined in Figure 5.4, the issue was to determine the extent to which the knowledge of MS was applied at various levels within the various folios. This was not easy and several approaches were tried. Evidence was there within the data, but how to make sense out of the data remained a problem. It was only after several trials that a reasonable approach emerged comprising two routes. While one route involved following the profiles in individual folios (representing individual students) across all sections (1-7), the other was about following sections, from Folio 1 to Folio 23 (see Figure 5.4 for sense of orientation). However, there was need to summarize and have an over-view of this information in order to make sense and meaning out of it. It was also necessary to establish a system of interpreting the data and in view of the two routes highlighted above, the idea was to come up with ways that could be used to put the data in specific units for the purpose of interpretation. This resulted in two scales designed according to the nature of data at hand. In both cases, the scale was based on the range of scores in Figure 5.4.

\begin{tabular}{|c|c|c|c|c|c|c|c|c|}
\hline Folios & Sec. 1 & Sec. 2 & 3 & 4 & 5 & 6 & 7 & $\begin{array}{l}\text { Total } \\
\text { Scores }\end{array}$ \\
\hline 1 & & $\sqrt{ } \sqrt{ }$ & & & & $\sqrt{ } \sqrt{ } \sqrt{ } \sqrt{ }$ & $\sqrt{ } \sqrt{ } \sqrt{ } \sqrt{ } \sqrt{ }$ & 13 \\
\hline 2 & & $\sqrt{ } \sqrt{ } \sqrt{ } \sqrt{ }$ & $\sqrt{ } \sqrt{ } \sqrt{ } \sqrt{ } \sqrt{ }$ & & $\sqrt{ }$ & $\sqrt{ } \sqrt{ } \sqrt{ } \sqrt{ }$ & $\sqrt{ } \sqrt{ } \sqrt{ } \sqrt{ } \sqrt{ } \sqrt{ } \sqrt{ } \sqrt{ }$ & 28 \\
\hline 3 & & $\sqrt{ } \sqrt{ }$ & $\sqrt{ }$ & & $\sqrt{ }$ & $\sqrt{ } \sqrt{ } \sqrt{ }$ & $\sqrt{ } \sqrt{ } \sqrt{ } \sqrt{ } \sqrt{ }$ & 17 \\
\hline 4 & & $\sqrt{ } \sqrt{ } \sqrt{ }$ & $\sqrt{ } \sqrt{ }$ & & $\sqrt{ } \sqrt{ }$ & $\sqrt{ } \sqrt{ } \sqrt{ }$ & $\sqrt{ } \sqrt{ } \sqrt{ }$ & 16 \\
\hline 5 & & $\sqrt{ } \sqrt{ }$ & & & $\sqrt{ } \sqrt{ } \sqrt{ } \sqrt{ }$ & $\sqrt{ } \sqrt{ } \sqrt{ } \sqrt{ }$ & $\sqrt{ } \sqrt{ } \sqrt{ } \sqrt{ }$ & 18 \\
\hline 6 & & $\sqrt{ } \sqrt{ } \sqrt{ } \sqrt{ }$ & & $\sqrt{ }$ & $\sqrt{ }$ & $\sqrt{ } \sqrt{ } \sqrt{ }$ & $\sqrt{ } \sqrt{ } \sqrt{ } \sqrt{ } \sqrt{ }$ & 18 \\
\hline 7 & & $\sqrt{ } \sqrt{ } \sqrt{ }$ & & & $\sqrt{ } \sqrt{ }$ & $\sqrt{ } \sqrt{ }$ & $\sqrt{ } \sqrt{ } \sqrt{ }$ & 14 \\
\hline 8 & & $\sqrt{ }$ & $\sqrt{ } \sqrt{ }$ & & & $\sqrt{ } \sqrt{ } \sqrt{ } \sqrt{ } \sqrt{ }$ & $\sqrt{ } \sqrt{ } \sqrt{ } \sqrt{ } \sqrt{ }$ & 16 \\
\hline 9 & & $\sqrt{ }$ & $\sqrt{ } \sqrt{ } \sqrt{ } \sqrt{ }$ & & $\sqrt{ } \sqrt{ } \sqrt{ }$ & $\sqrt{ } \sqrt{ } \sqrt{ } \sqrt{ }$ & $\sqrt{ } \sqrt{ } \sqrt{ }$ & 18 \\
\hline 10 & & & $\sqrt{ } \sqrt{ } \sqrt{ } \sqrt{ }$ & $\sqrt{ }$ & $\sqrt{ } \sqrt{ } \sqrt{ } \sqrt{ } \sqrt{ }$ & $\sqrt{ } \sqrt{ }$ & $\sqrt{ } \sqrt{ } \sqrt{ } \sqrt{ } \sqrt{ }$ & 21 \\
\hline 11 & & $\sqrt{ } \sqrt{ } \sqrt{ } \sqrt{ } \sqrt{ }$ & $\sqrt{ }$ & $\sqrt{ }$ & $\sqrt{ } \sqrt{ } \sqrt{ } \sqrt{ } \sqrt{ }$ & $\sqrt{ } \sqrt{ } \sqrt{ }$ & $\sqrt{ } \sqrt{ } \sqrt{ }$ & 24 \\
\hline 12 & & $\sqrt{ } \sqrt{ } \sqrt{ } \sqrt{ }$ & $\sqrt{ } \sqrt{ } \sqrt{ }$ & $\sqrt{ } \sqrt{ } \sqrt{ }$ & & $\sqrt{ } \sqrt{ } \sqrt{ } \sqrt{ } \sqrt{ } \sqrt{ }$ & $\sqrt{ } \sqrt{ } \sqrt{ } \sqrt{ }$ & 25 \\
\hline 13 & $\sqrt{ }$ & $\sqrt{ }$ & $\sqrt{ } \sqrt{ } \sqrt{ } \sqrt{ } \sqrt{ } \sqrt{ } \sqrt{ } \sqrt{ }$ & & $\sqrt{ } \sqrt{ } \sqrt{ } \sqrt{ }$ & $\sqrt{ } \sqrt{ }$ & $\sqrt{ } \sqrt{ }$ & 24 \\
\hline 14 & & $\sqrt{ }$ & $\sqrt{ } \sqrt{ } \sqrt{ } \sqrt{ } \sqrt{ } \sqrt{ } \sqrt{ }$ & & $\sqrt{ } \sqrt{ }$ & $\sqrt{ } \sqrt{ } \sqrt{ }$ & $\sqrt{ } \sqrt{ } \sqrt{ }$ & 20 \\
\hline 15 & & $\sqrt{ } \sqrt{ } \sqrt{ }$ & $\sqrt{ } \sqrt{ } \sqrt{ }$ & & & $\sqrt{ } \sqrt{ } \sqrt{ } \sqrt{ }$ & $\sqrt{ } \sqrt{ }$ & 16 \\
\hline
\end{tabular}




\begin{tabular}{|c|c|c|c|c|c|c|c|c|}
\hline Folios & Sec. 1 & Sec. 2 & 3 & 4 & 5 & 6 & 7 & $\begin{array}{l}\text { Total } \\
\text { Scores }\end{array}$ \\
\hline 16 & & & & & $\sqrt{ }$ & $\sqrt{ } \sqrt{ } \sqrt{ } \sqrt{ } \sqrt{ }$ & $\sqrt{ } \sqrt{ }$ & 10 \\
\hline 17 & $\sqrt{ }$ & $\sqrt{ }$ & & & $\sqrt{ }$ & $\sqrt{ } \sqrt{ } \sqrt{ } \sqrt{ }$ & $\sqrt{ }$ & 10 \\
\hline 18 & & $\sqrt{ } \sqrt{ } \sqrt{ }$ & $\sqrt{ } \sqrt{ } \sqrt{ } \sqrt{ } \sqrt{ } \sqrt{ } \backslash \sqrt{ }$ & & $\sqrt{ } \sqrt{ } \sqrt{ }$ & $\sqrt{ } \sqrt{ } \sqrt{ } \sqrt{ } \sqrt{ } \sqrt{ } \sqrt{ }$ & $\sqrt{ } \sqrt{ } \sqrt{ } \sqrt{ } \sqrt{ } \sqrt{ }$ & 33 \\
\hline 19 & & $\sqrt{ } \sqrt{ } \sqrt{ }$ & $\sqrt{ } \sqrt{ }$ & & $\sqrt{ }$ & $\sqrt{ } \sqrt{ } \sqrt{ } \sqrt{ } \backslash \sqrt{ } \sqrt{ }$ & $\sqrt{ }$ & 16 \\
\hline 20 & & $\sqrt{ } \sqrt{ }$ & $\sqrt{ } \sqrt{ } \sqrt{ } \sqrt{ } \sqrt{ } \sqrt{ }$ & $\sqrt{ } \sqrt{ } \sqrt{ } \sqrt{ } \sqrt{ }$ & $\sqrt{ } \sqrt{ } \sqrt{ } \sqrt{ }$ & $\sqrt{ } \sqrt{ } \sqrt{ } \sqrt{ } \sqrt{ } \sqrt{ }$ & $\sqrt{ } \sqrt{ } \sqrt{ } \sqrt{ }$ & 34 \\
\hline 21 & & $\sqrt{ } \sqrt{ }$ & & & $\sqrt{ }$ & $\sqrt{ } \sqrt{ } \sqrt{ } \sqrt{ } \sqrt{ } \sqrt{ } \sqrt{ }$ & $\sqrt{ } \sqrt{ } \sqrt{ }$ & 15 \\
\hline 22 & & $\sqrt{ } \sqrt{ } \sqrt{ }$ & & & $\sqrt{ }$ & $\sqrt{ } \sqrt{ } \sqrt{ } \sqrt{ } \sqrt{ } \sqrt{ } \sqrt{ }$ & $\sqrt{ } \sqrt{ } \sqrt{ }$ & 17 \\
\hline 23 & & $\sqrt{ } \sqrt{ } \sqrt{ }$ & $\sqrt{ } \sqrt{ } \sqrt{ } \sqrt{ } \sqrt{ } \sqrt{ } \sqrt{ }$ & & $\sqrt{ } \sqrt{ } \sqrt{ } \sqrt{ } \sqrt{ }$ & $\sqrt{ } \sqrt{ } \sqrt{ }$ & $\sqrt{ } \sqrt{ } \sqrt{ } \sqrt{ } \sqrt{ }$ & 29 \\
\hline Totals & 2 & 69 & 78 & 13 & 59 & 123 & 107 & \\
\hline
\end{tabular}

Figure 5.4

An excerpt showing how scores were entered for folios 1-23

Every tick stands for an indication (clue/evidence) of MS having been applied.

After determining the sense of both sets of scores, it was then possible to group/categorize them into the following levels in ascending order: Very Low; Low; Moderate; High and Very High. This was the sense in which the results and findings in Figure 5.4 could be interpreted in tables 5.4.2 and 5.4.3. For the sake of clarity, rows 1-23 in Figure 5.4 stand for the number of folios analysed while columns 1-7 stand for the stages in the design process, translating to the seven sections of the design folio.

Table 5.4.2

Results and findings according to the first scale (Going by folio profile)

\begin{tabular}{|c|c|c|}
\hline Score Range & Level & No. of Folios \\
\hline $1-9$ & Very Low & 4 \\
\hline $10-14$ & Low & 11 \\
\hline $15-20$ & Moderate & 3 \\
\hline $21-24$ & High & 5 \\
\hline $25-\&$ above & Very High & 0 \\
\hline
\end{tabular}


The results and findings in Table 5.4.2 show that, in one way or another, all teachers applied their knowledge of MS in solving practical problem during activities in MsP. The only difference was the extent and level of that application, depending on individuals.

Table 5.4.3

Results and findings according to the second scale (Going by sections)

\begin{tabular}{|c|c|c|}
\hline Score Range & Level & Folios Section(s) \\
\hline $1-10$ & Very Low & 1 \\
\hline $11-40$ & Low & $2 \& 5$ \\
\hline $41-70$ & Moderate & 3 \\
\hline $71-100$ & High & $6 \& 7$ \\
\hline $101-\&$ above & Very High & 4 \\
\hline
\end{tabular}

Table 5.4.3 shows that the application of MS during MsP, as reflected in the folios varied in intensity, depended on various sections. While there was more evidence of application in some sections (e.g.6\&7), there was much less in others (e.g.1\&4).

Having achieved an overview of the picture emerging from tables 5.4.2 and 5.4.3, one could sum up the general observations and say that there was adequate/satisfactory evidence of teachers really applying their knowledge of MS during MsP, despite differences in intensity of application. All bits and pieces of evidence, leading to the results and findings presented here have mainly served to confirm and qualify most claims made by teachers during interviews and discussions.

\section{Discussion of conclusions and their implications}

Conclusions were drawn in line with the research questions, going as follows:

- MS and MsP courses were found reflective of each other.

- Several aspects of MS were found applicable during problem-solving under MsP.

- Students did reflect on their knowledge MS during problem-solving under MsP. 
- Generally there was adequate evidence of students applying their knowledge of MS during problem-solving activities under MsP.

- Having students being able to apply their knowledge of MS as they solved specific practical problems under MsP had several implications on the issue of outcome/competence-based learning at the University of Zimbabwe.

The fact that the two courses; MS and MsP were found closely related and reflective of each other proved to be very useful in promoting subject integration between them. It also helped to prove the relevance of each course to the common purpose of skills development within the context of outcome/competency-based learning. Linking and relating the two courses conceptually and practically in the manner reflected in this study has several implications on the issue of assessment and accreditation, where efficiency is promoted by cross-checking and triangulating assessment mechanisms for the development of realistic learning outcomes between the two courses. Competency-based learning, being a relatively new phenomenon at the University of Zimbabwe, there is a high potential of this study providing important lessons to other sections of the University, particularly in the Faculty of Education. Currently, developments in competency-based teacher education (CBTE) present both; possibilities and challenges. Besides the need to be clear on the specification of learning strategies or formats, there is still need to provide a clear description of intended learning outcomes (ILOs).

According to Smith and Dollase ${ }^{79}$ the outcome/competency-based learning approach has the potential to yield authentic curricula for various fields. In this case, such a potential is also likely to be felt in teacher education, where the challenge has been to have teachers coping up with rapid changes in education, particularly now (2017) when our system has undergone a rigorous review process at all levels, in view of the Zimbabwe Agenda for Sustainable Socio-Economic Transformation (ZIMASSET). According to Government, the success of this policy development squarely depends on the strength of the education system at all levels. ${ }^{80}$

79 Stephen R. Smith and Richard Dollase, "Outcome based education: Part 2 - Planning, implementing and evaluating a competency-based curriculum," Med.Teach 21, no. 1 (1999): $15-22$.

${ }^{80}$ Government of Zimbabwe, Zimbabwe Agenda for Sustainable Socio-Economic Zimbabwe Agenda for Sustainable Socio-Economic Transformation (ZimAsset); Towards an Empowered Society and a Growing Economy - October 2013-December 2018 (Harare: Government printers, 2013). 
Observations by Harris et al ${ }^{81}$ have provided adequate evidence proving that outcome- or competency-based learning frameworks and systems are designed to move/go beyond routine curricular renewal. Unfortunately, in Zimbabwean, there still appears to be a lack of a consistent language surrounding these frameworks, along with an underlying lack of conceptual clarity. To a large extent, this has been a major obstacle to the advancement of outcome- or competence based learning at various levels. One bone of contention in the discussion of any outcome/competency-based teacher education curriculum model is the notion of separate and independent competencies, given that competencies or capabilities reside in integrated professional performance. At least for this study, this notion has to an extent been broken by the promotion of a form of subject integration between MS and MsP. The conviction in this study was to contribute to a system that would help prepare students for lifelong learning by increasing their involvement in decisions-making about their own learning; thereby tracking their own progress. This was based on the belief that outcome/competencybased learning provides a focus on reflective and developmental activities, which Candy and associates ${ }^{82}$ have placed at the very core of all learning activities, in keeping with one of the requirements of higher education; fostering the development and transformation of students. Such transformation involves the provision of tools to assist student in continuing to learn. ${ }^{83} \mathrm{~A}$ clearly articulated framework of practical, real-world objectives provides a rare opportunity for students to develop a clear pathway toward relevant competencies. In most cases this has been a departure from many previous curricula that have relied on a stratification of experiences; rarely building upon one another and remaining fragmented without a comprehensive framework.

However, despite all these advantages, outcome/competency-based Learning models have always raised several issues and problems in the areas of design, assessment, and systemic factors, all of which have also impacted upon teachers and learners. ${ }^{84}$ Effectively, these are areas still in need of further research.

${ }^{81}$ Harris et al., "Competency-based medical education," 1.

${ }^{82}$ Philip C. Candy et al., "Developing lifelong learners through undergraduate education," in National Board of Employment, Education and Training Commissioned Report No. 28, ed. Philip C. Candy et al (Canberra - ACT: Australian Government Publishing Service, 1994).

${ }^{83}$ Susan Toohey, Designing courses for higher education (Buckingham, UK: Society for Research into Higher Education, 1999).

${ }^{84}$ Harris et al., "Competency-based medical education," 2. 


\section{Bibliography}

Apple, W. Michael. "The politics of official knowledge in the United States." Journal of Curriculum Studies 22, no. 4 (1990): 377-383.

Barrow, Robin. Giving teaching back to teachers: A critical introduction to curriculum theory. Sussex: Wheatheaf Books, 1984.

Berlak, Ann, and Harold Berlak. "Towards a non-hierarchical approach to inquiry and leadership." Curriculum Inquiry 13, no. 3 (1983): 267-294.

Bowers, Alex C., and David J. Flinders. Responsive teaching. New York: Teachers' College Press (Columbia University), 1990.

Bowser, Wayland. "Reforming design education." Journal of Architectural Education 37, no. 2 (1983): 1-37.

Bradley, D. John. "Science education at the RADMASTE Centre: The role of the university in development." In Science and environment education: Views from developing countries, edited by S. Ware, 141-150. Washington: The World Bank, 1999.

Candy, Philip C., Gay Crebert, and Jane O'Leary. "Developing lifelong learners through undergraduate education." In National Board of Employment, Education and Training Commissioned Report No. 28, edited by Philip C. Candy, Gay Crebert, and Jane O'Leary. Canberra: Australian Government Publishing Service, 1994.

Cornbleth, Catherine. "Ritual and rationality in teacher education reform." Educational Researcher 15, no. 4 (1986): 5-14.

- Curriculum in context. New York: The Falmer Press, 1990.

Dewey, John. "Individuality and experience." In Art and Education, 180. Marion Pa.: Barnes Foundation, 1929.

—. John Dewey on education: Selected writings. edited by Reginald D. Archambault. New York: Random House, 1964.

Doll, C. Ronald. Curriculum improvement: Decision making and process. Boston: Allyn and Bacon, 1996.

Donald, David, Sandy Lazarus, and Peliwe Lolwana. Educational psychology in social context. London: Sage Publications, 2002.

English, W. Fenwick. "Contemporary curriculum circumstances." In Fundamental curriculum designs, edited by Fenwick W.English, 1-17. California: ASCD Yearbook, 1983.

Freire, Paulo. Pedagogy of the oppressed. New York: Herder and Herder, 1970.

. Pedagogy of the oppressed. Englewood Cliffs N.J.: Prentice Hall, 1972.

. The politics of education, culture, Power and liberation. South Hadley, Mass.: Bergin and Garvey, 1985.

- Pedagogy of the oppressed. New York: Continuum, 1990.

Gagne, R. Mills. The condition of learning, New York: Holt, Rinehart and Winston, 1987.

Gagnier, Regenia. "Feminist postmodernism: The end of theory?" In Theoretical perspectives on sexual differences, edited by Deborar L. Rhode, New Haven, Conn.: Yale University Press. 1990. 
Garratt, James. Design and technology. London: Cambridge University Press, 1995. Ginsburg, B. Mark. "Reproduction, contradictions, and conceptions of curriculum in pre-service teacher education.” Curriculum Inquiry 16, no. 3 (1986): 283-309.

Glenn, D. Allen and Carol A. Carrier. "Teacher education and computer training: An assessment (Beyond the computer revolution)." Peabody Journal of Education 64, no. 1 (1986): 67-80.

Government of Zimbabwe. Zimbabwe Agenda for Sustainable Socio-Economic Zimbabwe Agenda for Sustainable Socio-Economic Transformation (ZimAsset): Towards an Empowered Society and a Growing Economy October 2013-December 2018. Harare: Government printers, 2013.

- Zimbabwe Education Blueprint 2015-2022: Curriculum Framework for Primary and Secondary Education. Harare: Government printers, 2015.

Harris, Peter, Linda Snell, Martin Talbot, and Ronald M. Harden. Competency-based medical education: Implication for undergraduate programmes. Edited by Medical Faculty, University of Sydney: New South Wales, 2010.

Harvey, David. The Condition of Post-Modernity. Oxford: Basil Blackwell, 1992.

Keeves, P. John and Glen S. Aikenhead. "Science curriculum in changing world." In Improving science education, edited by B. F. Fraser and H. J. Walberg, 13-45. Chicago: The National Society for the Study of Education, 1995.

Kelly, A. Victor. Curriculum context: A comparative approach. London: Happer and Row Publishers, 1980.

Kilpatrick, W. Heard. Foundation of education. New York: Macmillan, 1926.

Kohl, Herbert. "Towards educational change and economic justice." Phi Delta Kappan 72, no. 9 (1991): 678-681.

Kwaira, Peter. "A study to determine the extent to which the Design and Technology approach is being relevant to the teaching of technical subjects in Zimbabwe." In Proceedings of the eighth annual meeting of the Southern African Association for Research in Mathematics and Science Education, edited by Sechaba Mahlomaholo. Port Elizabeth: University of Port Elizabeth, 2000.

Kwaira, Peter. "Problems experienced by teachers in their efforts to implement the Design and Technology approach in the teaching of technical subjects." In IDATER'98, edited by Smith, J. S, 224-229. Loughborough: Department of Design and Technology — Loughborough University, 1998.

Kyriacou, Chris. Effective teaching in schools. New York: Simon \& Schuster Education, 1994.

Lazarowtz, Reuven, and Pinchas Tamir. "Research on using laboratory in science instruction." In A handbook of research in science teaching and learning, edited by Dan Gabel, 94-128. New York: Macmillan, 1994.

Mafumiko, Fidelis, and Wout Ottevanger. "Micro-scale experiments in improving practical chemistry in Tanzania secondary science education." In Science education research and teacher development in Tanzania, edited by Osaki, K. et al. 121-134. Amsterdam: VrijeUniversiteit Amsterdam — International Cooperation Centre, 2002. 
Marsh, J. Colin, and George Willis. Curriculum: Alternative approaches, ongoing issues. Columbus, Ohio: Merrill, 2003.

McNeil, John. Curriculum: A comprehensive introduction. Glenview III: Scott Foreman, 1990.

Meachum, J. Shuaib. "Vygotsky and the blues: Re-reading cultural connections and conceptual development." Theory into Practice 40 (2001): 190-197.

Melnick, Blake. "Virtual Schools: The changing face of education - Learning with technology." The English Journal: The world of literature 91, no. 5 (2002): 85-88.

Moore,W. Terry. Philosophy of education - An introduction. London: Routledge and Kegan Paul, 1982.

Mumford, Enid. "Participation systems design: Practice and theory." Journal of Occupational Behaviour 4, no. 1 (1983): 47-57.

National Commission for Excellence in Teacher Education (NCETE). A call for change in teachers education. Washington, DC: American Association of Colleges in Teacher Education, 1985.

National Conference on Teacher Education Report (NCTER), Teacher education for the 21st. century: Issues and strategies. Harare: Ministry Of Education and Culture - Zimbabwe, 2000.

Neville, C. Robert. The high road around modernism. Albany: State University of New York Press, 1992.

Ornstein, C. Allan and Francis P. Hunkins. Curriculum foundations, principles, and issues. London: Allyn and Bacon, 2004.

Oxford, L. Richardson. "Constructivism: Shape-shifting, substance, and teacher education applications." Peabody Journal of Education 72, no. 1 (1997): 35-66.

Patton, M. Quinn. Qualitative research and evaluation methods. London: Sage Publications - International and Professional Publisher, 2002.

Peters, Michael. Education and the postmodern condition. Westport, Conn.: Bergin and Garvey, 1995.

Peters, R. Stanley. The philosophy of science. London: Oxford University Press, 1973.

Pinar, F. William. "Farewell and celebrate". In Contemporary curriculum discourses, edited by William F. Pinar, New York: Peter Lang, 1999.

Posner, J. George. Analysing the curriculum. New York: McGraw-Hill, 1992.

Powell, J.Carlson and Ronald D. Anderson. 'Changing teachers' practice: Curriculum materials and science education reform in the USA.' Studies in science education 37 (2002): 107-136.

Pratt, David. Curriculum planning. New York: Harcourt Brace College Publishers, 1994.

Robson, Colin. Real world research: A resource for social scientists and practitionerresearchers. Oxford, UK: Blackwell Publishers, 1993.

Seigfried, C. Haddock. Pragmatism and Feminism. Chicago: University of Chicago Press, 1996.

Slattery, Patrick. Curriculum development in the postmodern era. New York: Garland Publishing, 1995. 
Smith, R. Stephen, and Richard Dollase. "Outcome based education: Part 2 Planning, implementing and evaluating a competency-based curriculum." Medical Teacher 21, no. 1 (1999): 15-22.

Sowell, J. Evelyn. Curriculum: An integrative introduction. Upper Saddle River, NJ: Merrill, An imprint of Prentice Hall, 1996.

Toohey, Susan. Designing courses for higher education. Buckingham, UK: Society for Research into Higher Education, 1999.

Van den Akker, Jan. "Principles and methods of development research'. In Design approaches and tools in education and training edited by Jan van den Akker, R. Branch, K. Gustafson, N. Nieveen and T. J. Plomp, 1-14. Dordrecht: Springer Science+Business Media, 1999.

Vygotsky, S. Lev. Thought and language. Edited by Alex Kozulin, Cambridge: The MIT Press, 1986.

Ware, Sylvia. Secondary school science in developing countries. Washington, DC: The World Bank, 1992.

Wiles, Jon. Curriculum essentials: A resource for educators. New York: Pearson Education, Inc., 2005.

Zvobgo, R. Jonas. Transforming education: The Zimbabwean experience. Harare: The College Press, 1986.

\section{About the author}

PETER ANTONIO KWAIRA (Petkwaira@gmail.com), PhD in Science and Technology Education, has been with the University of Zimbabwe, in Zimbabwe, since 1989. He is currently a Senior Lecturer in the Department of Technical Education, teaching; Principles of Design, Principles of Material Science, History and Philosophy of Technical Education, Entrepreneurship and Project Management, Applied Physics and Research Method to both Bachelor and Masters' degree levels. His area of specialization is Technical Education, where his research interests are mainly in the areas of Design and Technology Education, Teacher Education, Curriculum Design and Development, Product Design and Development, Distance Education, Sustainable Development, Food Production and Processing, and Community Development. 


\section{Students applying their knowledge of material science in problem-solving: implications for competence based-learning at the University of Zimbabwe}

Peter Kwaira

\section{Copyright}

Copyright for this article is retained by the Publisher. It is an Open Access material that is free for download, distribution, and or reuse in any medium only for non-commercial purposes; provided any applicable legislation is respected, the original work is properly cited, and any changes to the original are clearly indicated. 